\title{
Peningkatan Kompetensi Kognitif Siswa Terhadap Pemahaman Materi Kedaulatan Rakyat Dan Sistem Pemerintahan Di Indonesia Dalam Pembelajaran PKn Melalui Keterpaduan Metode Role Playing Dan Simulation Siswa Kelas X.1 SMA Negeri 1 Bengo Kabupaten Bone
}

\author{
Muhammad Tang \\ SMA Negeri 1 Bengo Kab. Bone \\ Email: muhammadtang71@gmail.com
}

\begin{abstract}
Abstrak: Masalah penelitian ini, yaitu apakah hasil belajar PKn materi kedaulatan rakyat dan sistem pemerintahan di Indonesia dapat ditingkatkan melalui metode simulasi kreatif pada siswa kelas X.1 SMA Negeri 1 Bengo Kabupaten Bone. Berdasarkan permasalahan dalam penelitian ini, diupayakan pemecahan masalah hasil belajar PKn materi kedaulatan rakyat dan sistem pemerintahan di Indonesia melalui metode simulasi kreatif pada siswa kelas X.1 SMA Negeri 1 Bengo Kabupaten Bone. Tujuan penelitian ini adalah untuk mendeskripsikan peningkatan hasil belajar PKn materi kedaulatan rakyat dan sistem pemerintahan di Indonesia melalui metode simulasi kreatif pada siswa kelas X.1 SMA Negeri 1 Bengo Kabupaten Bone. Penelitian ini adalah penelitian tindakan kelas (PTK), dengan menggunakan pendekatan kualitatif deskriptif. Fokus penelitian ini adalah peningkatan proses dan hasil belajar PKn materi kedaulatan rakyat dan sistem pemerintahan di Indonesia. Pengumpulan data dilakukan melalui observasi dan tes. Teknik analisis data yang digunakan adalah model analisis data yang terdiri atas tiga alur kegiatan, yaitu reduksi data, penyajian data dan penarikan kesimpulan/verifikasi. Hasil penelitian menunjukkan bahwa metode simulasi kreatif dapat meningkatkan kreativitas dan hasil belajar siswa. Hal ini dapat dilihat pada hasil penelitian yang menyatakan bahwa kreativitas siswa mengalami peningkatan pada saat guru menggunakan Metode Simulasi Kreatif pada pelajaran Kedaulatan Rakyat dan Sistem Pemerintahan di Indonesia. Peningkatan ini dapat dilihat baik pada setiap siklus pada kelas terteliti
\end{abstract}

\section{Kata kunci: Kognitif Siswa, Metode Role Playing, dan Simulation}

\begin{abstract}
The problem of this research, namely whether the Civics learning outcomes of material sovereignty of the people and the system of government in Indonesia can be improved through creative simulation methods in class X.1 students of SMA 1 Bengo, Bone Regency. Based on the problems in this study, efforts were made to solve the problem of Civics learning outcomes in the matter of people's sovereignty and system of governance in Indonesia through creative simulation methods in class X.1 Bengo 1 Senior High School Bone District. The purpose of this study was to describe the improvement in Civics learning outcomes of material sovereignty and the system of government in Indonesia through creative simulation methods in class X.1 Bengo 1 Senior High School Bone District. This research is classroom action research (PTK), using a descriptive qualitative approach. The focus of this research is to improve the process and learning outcomes of Civics in the matter of people's sovereignty and the system of government in Indonesia. Data collection is done through observation and tests. The data analysis
\end{abstract}




\section{JIKAP PGSD: Jurnal Ilmiah Ilmu Kependidikan}

technique used is a data analysis model consisting of three activity lines, namely data reduction, data presentation and conclusion / verification. The results of the study show that creative simulation methods can improve creativity and student learning outcomes. This can be seen in the results of the study stating that the creativity of students has increased when the teacher uses the Creative Simulation Method in the lessons of the People's Sovereignty and Government System in Indonesia. This increase can be seen both in each cycle in the researched class

Keywords: Student Cognitive, Role Playing, and Simulation Methods

\section{PENDAHULUAN}

Dalam penyelenggaraan sistem pendidikan nasional, Pemerintah dan Pemerintah Daerah wajib memberikan layanan dan kemudahan, serta menjamin terselenggaranya pendidikan yang bermutu bagi setiap warga negara tanpa diskriminasi (Pasal 11 ayat (1) UU. No. 20 Tahun 2003 Tentang Sisdiknas). Selanjutnya Pasal 11 ayat (2) menegaskan "Pemerintah dan Pemerintah Daerah wajib menjamin tersedianya dana guna terselenggaranya pendidikan bagi setiap warga negara yang berusia tujuh sampai dengan lima belas tahun".

Mencermati uraian tersebut maka diharapkan pembelajaran PKn dapat ditingkatkan agar dapat mencapai hasil yang maksimal sesuai dengan tuntutan kurikulum. Selain itu, Pendidikan Kewarganegaraaan (PKn) dimaksudkan untuk membentuk peserta didik menjadi manusia yang memiliki rasa kebangsaan dan cinta tanah air, membekali siswa dengan budi pekerti, pengetahuan, dan kemampuan dasar berkenaan dengan hubungan antara sesama warga negara maupun antarwarga negara serta pendidikan pendahuluan bela negara agar menjadi warga negara yang dapat diandalkan oleh bangsa dan negara.

Pembelajaran PKn digalakkan di sekolah dengan harapan dapat mengembangkan pengetahuan dan kemampuan siswa memahami dan menghayati nilai-nilai Pancasila dalam rangka pembentukan sikap dan perilaku sebagai pribadi, anggota masyarakat dan warga negara yang bertanggung jawab serta membekali bekal kemampuan untuk mengikuti pendidikan dijenjang pendidikan menengah.

Pelaksanaan pengajaran PKn di SMA dilaksanakan secara terpadu dan bertitik tolak dari tema sebagai pusat (centre core). Sajian materi dalam GBPP adalah terpadu antara kemampuan kebahasaan, pemahaman, dan penggunaan. Dalam KBM, guru dapat memilih mana yang menjadi pokok utama. Tema berfungsi sebagai tali ikatan dalam satu pelajaran. Dalam satu pelajaran sub-sub pelajaran tidak berdiri sendiri tetapi saling berhubungan. Dengan demikian segala sesuatu yang dibicarakan dalam pengajaran tersebut, adalah menyangkut temanya.

Namun, fenomena menunjukkan beberapa tahun terakhir bahwa hasil belajar siswa untuk bidang studi PKn sangat rendah. Di antara 35 orang siswa masih ada $60 \%$ atau sekitar 21 orang yang memperoleh nilai 55 ke bawah. Hal ini berarti 21 orang siswa ini dinyatakan tidak lulus untuk bidang studi PKn karena standar nilai kriteria ketuntasan minimal (KKM) yang ditetapkan adalah 7,0. Standar nilai KKM adalah standar nilai yang dijadikan sebagai batasan nilai minimun atau terendah yang harus dicapai siswa agar dinyatakan lulus.

Mencermati hasil belajar tersebut, perlu pengembangan pembelajaran PKn dengan menerapkan metode yang berbasis kreativitas siswa, seperti melalui keterpaduan metode role playing dan simulation. Pengembangan melalui keterpaduan metode role playing dan simulation perlu kiranya mendapat perhatian yang memadai. Disebut demikian karena melalui keterpaduan metode role playing dan simulation dalam konteks pembelajaran aktivitasnya dapat dijadikan wahana pembuahan pengalaman, penyampaian informasi dan pengintegrasian antara sesuatu dengan dunia realisasi (Aminuddin, 1997: 1).

Sehubungan dengan hal tersebut, penggunaan melalui keterpaduan metode role playing dan simulation dalam konteks pembelajaran PKn memerlukan daya kreatif kepekaan daya adaptasi guru. Hal yang demikian itu akan dapat ikut serta meningkatkan keberhasilan pembelajaran yang diwarnai rasa kesenangan.

Keterpaduan metode role playing dan simulation dalam bentuk simulasi digunakan sebagai alat pendidikan. Simulasi pendidikan mempunyai tujuan utama yakni agar anak 
belajar. Guru berperan secara kreatif untuk merencanakan simulasi yang dapat digunakan sebagai sarana pembelajaran di sekolah.

Dalam konteks pembelajaran bahasa, melalui keterpaduan metode role playing dan simulation, bermanfaat dalam mengembangkan kemampuan menyimak, menulis, membaca, maupun berbicara. Pengembangan kemampuan tersebut bisa juga dihubungkan dengan pengembangan emosi, hubungan sosial, daya imajinasi, daya kreativitas, kemampuan berpikir kritis, daya fisikal, maupun isi pembelajaran dari mata pembelajaran lain secara terpadu.

Berdasarkan uraian di atas, peneliti berinisiatif untuk melakukan sebuah penelitian dengan judul Peningkatan Kompetensi Kognitif Siswa Terhadap Pemahaman Materi Kedaulatan Rakyat dan Sistem Pemerintahan di Indonesia dalam Pembelajaran PKn Melalui Keterpaduan Metode Role Playing dan Simulation Siswa Kelas X.1 SMA Negeri 1 Bengo Kabupaten Bone.

\section{METODE PENELITIAN}

Penelitian ini adalah penelitian tindakan kelas (PTK), dengan menggunakan pendekatan kualitatif deskriptif. Fokus penelitian ini adalah peningkatan hasil belajar PKn materi kedaulatan rakyat dan sistem pemerintahan di Indonesia melalui keterpaduan metode role playing dan simulation pada siswa kelas X.1 SMA Negeri 1 Bengo Kabupaten Bone.

Penelitian Tindakan Kelas (PTK) ini dilaksanakan pada siswa kelas X.1 SMA Negeri 1 Bengo Kabupaten Bone sebanyak 22 orang.

Peningkatan hasil belajar dalam pembelajaran difokuskan pada hasil pengamatan berdasarkan temuan di lapangan, hasil observasi, catatan lapangan, dan dokumentasi berupa catatan tindakan pembelajaran PKn dengan menggunakan metode role playing dan simulation. Data tersebut meliputi data perencanaan, data pelaksanaan, dan data evaluasi peningkatan hasil belajar

Pengumpulan data dalam penelitian ini dilakukan demgan tes dan lembar pengamatan. Teknik analisis data yang digunakan adalah model analisis data yang terdiri atas tiga alur kegiatan secara bersamaan, yaitu reduksi data, penyajian data dan penarikan kesimpulan/ verifikasi.

Indikator keberhasilan ketuntasan belajar jika ketuntasan belajar siswa mendapat nilai $70 \%$ ke atas maka pembelajaran dengan menggunakan metode simulasi oleh guru dapat berhasil efektif. Kategori yang telah ditentukan diberi nilai secara keseluruhan 10 masingmasing kategori, (Tarigan, 1990: 164).

Tabel 3.1: Teknik Kategorisasi Standar Ketuntasan Belajar

\begin{tabular}{cc}
\hline $\begin{array}{c}\text { Perolehan Prestasi } \\
\text { Belajar }\end{array}$ & Kategori \\
\hline $0-4,0$ & Sangat Rendah \\
\hline $4,1-5,5$ & Rendah \\
\hline $5,6-7,0$ & Sedang \\
\hline $7,1-8,5$ & Tinggi \\
\hline $8,6-10$ & Sangat Tinggi \\
\hline
\end{tabular}

\section{HASIL DAN PEMBAHASAN}

Berdasarkan metode yang digunakan dalam penelitian yaitu penelitian tindakan kelas, maka pada bagian ini dipaparkan tentang deskripsi setting penelitian (gambaran pelaksanaan penelitian). Penelitian dilakukan dengan beberapa tahap yang dilaksanakan ke dalam dua siklus. Adapun tahap-tahap dalam penelitian secara umum dapat diuraikan sebagai berikut:

1. Guru dan peneliti secara kolaborasi menyusun rencana pembelajaran.

2. Peneliti/guru memberikan sebuah materi diri sendiri untuk dilaksanakan simulasi sesuai petunjuk dalam LKS.

3. Guru memberikan contoh cara melaksanakan simulasi sesuai petunjuk dalam LKS.

4. Guru/peneliti mengarahkan siswa tentang hal-hal yang diperhatikan

5. Guru membimbing siswa untuk berani tampil di depan kelas dalam melaksanakan simulasi sesuai petunjuk dalam LKS.

6. Guru bersama peneliti melakukan diskusi (merefleksi) tindakan yang telah dilakukan.

7. Secara kolaborasi peneliti dan guru melakukan.

8. Berdasarkan tahap-tahap penelitian di atas dapat diuraikan pelaksanaannya yang dijabarkan ke dalam dua siklus penelitian berikut.

\section{a. Hasil Observasi Aktivitas Siswa}

Berdasarkan hasil yang telah diperoleh dan telah diklasifikasikan tentang tingkat hasil belajar siswa dengan Metode Simulasi Kreatif, maka diketahui bahwa rata-rata hasil belajar pertemuan pertama siklus I sebesar 6,82 . Sementara distribusi hasil belajar PKn, dapat dilihat pada tabel di bawah ini: 
JIKAP PGSD: Jurnal Ilmiah Ilmu Kependidikan

Tabel 4.1. Distribusi Hasil Belajar Siswa Pertemuan Pertama Siklus I

\begin{tabular}{|c|c|c|c|}
\hline Perolehan Hasil Belajar & Kategori & Jumlah (n) & Persentase $(\%)$ \\
\hline $0-4,0$ & Sangat Rendah & - & - \\
\hline $4,1-5,5$ & Rendah & 1 & 4,55 \\
\hline $5,6-7,0$ & Sedang & 17 & 77,27 \\
\hline $7,1-8,5$ & Tinggi & 4 & 18,18 \\
\hline $8,6-10$ & Sangat Tinggi & - & - \\
\hline \multicolumn{2}{|c|}{ Juml } & 22 & 100 \\
\hline
\end{tabular}

Pada tabel di atas menunjukkan bahwa tingkat hasil belajar siswa dengan perolehan hasil belajar, dari 22 siswa pada pertemuan pertama siklus I, tidak ada siswa yang memperoleh hasil belajar sangat rendah $(0-4,0)$ dan hasil belajar sangat tinggi $(8,6-10)$, hasil belajar rendah $(4,1-5,5)$ sebanyak 1 siswa atau $4,55 \%$, hasil belajar sedang $(5,6-7,0)$ sebanyak 17 siswa atau $77,27 \%$, dan hasil belajar tinggi $(7,1-8,5)$ sebanyak 4 siswa atau $18,18 \%$.

Berdasarkan hasil yang telah diperoleh dan telah diklasifikasikan tentang tingkat hasil belajar siswa dalam dengan Metode Simulasi Kreatif, maka diketahui bahwa rata-rata hasil belajar pertemuan kedua siklus I sebesar 7,04\%. Sementara distribusi hasil belajar PKn, materi pada pertemuan pertama siklus I dengan Metode Simulasi Kreatif dapat dilihat pada tabel di bawah ini:

Tabel 4.2. Distribusi Hasil Belajar Siswa Pertemuan Kedua Siklus I

\begin{tabular}{|c|c|c|c|}
\hline Perolehan Hasil Belajar & Kategori & Jumlah (n) & Persentase $(\%)$ \\
\hline $0-4,0$ & Sangat Rendah & - & - \\
\hline $4,1-5,5$ & Rendah & - & - \\
\hline $5,6-7,0$ & Sedang & 15 & 68,18 \\
\hline $7,1-8,5$ & Tinggi & 7 & 31,82 \\
\hline $8,6-10$ & Sangat Tinggi & - & - \\
\hline \multicolumn{2}{|c|}{ Jumlah } & 22 & 100 \\
\hline
\end{tabular}

Pada tabel di atas menunjukkan bahwa tingkat hasil belajar siswa dengan perolehan hasil belajar, dari 22 siswa dengan Metode Simulasi Kreatif pada pertemuan kedua siklus I, tidak ada siswa yang memperoleh hasil belajar sangat rendah $(0-4,0)$ dan hasil belajar rendah $(4,1-5,5)$, dan hasil belajar sangat tinggi $(8,6-10)$, hasil belajar sedang $(5,6-7,0)$ sebanyak 15 siswa atau $68,18 \%$ dan hasil belajar tinggi $(7,1-8,5)$ sebanyak 7 siswa atau $31,82 \%$. Selanjutnya data pada tiap pertemuan selama siklus pertama di atas direkapitulasi untuk mengetahui hasil belajar rata-rata dan persentase hasil belajar siswa.

Tabel 4.3. Distribusi Rata-Rata Hasil Belajar Siswa Siklus I

\begin{tabular}{|c|c|c|c|c|c|c|}
\hline \multirow{2}{*}{$\begin{array}{c}\text { Perolehan } \\
\text { Hasil Belajar }\end{array}$} & \multirow{2}{*}{ Kategori } & \multicolumn{2}{|c|}{ Pertemuan Ke } & \multirow{2}{*}{ Jumlah } & \multirow{2}{*}{ Rata-Rata } & \multirow{2}{*}{$\begin{array}{l}\text { Persentase } \\
\quad(\%)\end{array}$} \\
\hline & & 1 & 2 & & & \\
\hline $0-4,0$ & Sangat Rendah & - & - & - & - & - \\
\hline $4,1-5,5$ & Rendah & 1 & - & 1 & 0,5 & 2,27 \\
\hline $5,6-7,0$ & Sedang & 17 & 15 & 32 & 16 & 72,73 \\
\hline $7,1-8,5$ & Tinggi & 4 & 7 & 11 & 5,5 & 25,00 \\
\hline $8,6-10$ & Sangat Tinggi & - & - & - & - & - \\
\hline \multicolumn{2}{|c|}{ Jumlah } & 22 & 22 & 44 & 22 & 100 \\
\hline
\end{tabular}

Berdasarkan data olahan hasil belajar, maka dapat dideskripsikan sebagai berikut bahwa dari 22 siswa Kelas X.1 SMA Negeri 1 Bengo Kabupaten Bone bahwa pada pertemuan siklus I yang mengikuti pelajaran PKn dengan Metode Simulasi Kreatif materi tingkat pencapaian ratarata prestasi belajar pada siklus I sebesar 6,93, ini berarti belum mencapai hasil ketuntasan belajar secara klasikal yang diharapkan yakni sebesar $70 \%$. Sementara distribusi rata-rata hasil belajar PKn, materi pada siklus I dengan Metode Simulasi Kreatif dapat dilihat pada tabel di bawah ini 
Pada tabel di atas menunjukkan bahwa rata-rata tingkat hasil belajar siswa dengan perolehan hasil belajar, dari 22 siswa dengan Metode Simulasi Kreatif pada siklus I, tidak ada siswa yang memperoleh hasil belajar sangat rendah $(0-4,0)$ dan hasil belajar sangat tinggi $(8,6$ - 10), hasil belajar rendah $(4,1$ - 5,5) sebanyak 0,5 siswa atau $2,27 \%$ hasil belajar sedang $(5,6-7,0)$ sebanyak 16 siswa atau $72,73 \%$ dan hasil belajar tinggi $(7,1-8,5)$ sebanyak 5,5 siswa atau $25,00 \%$.

Jumlah siswa yang tuntas dalam pembelajaran PKn di akhir siklus I masih kurang yaitu sebanyak 13 siswa $(59,09 \%)$. Secara rinci dapat digambarkan seperti pada tabel berikut ini.

Tabel 4.4. Klasifikasi Tingkat Prestasi Belajar Siklus I

\begin{tabular}{clcc}
\hline No & Perolehan Hasil Belajar & Frekuensi & Persentase \\
\hline 1 & Hasil belajar 7,0 ke atas & 13 & 59,09 \\
\hline 2 & Hasil belajar di bawah 7,0 & 9 & 40,91 \\
\hline & Jumlah & 22 & 100 \\
\hline
\end{tabular}

Berdasarkan hasil yang telah diperoleh dan telah diklasifikasikan tentang tingkat prestasi belajar dalam dengan metode Simulasi kreatif, maka diperoleh data bahwa pada siklus I yaitu 9 siswa yang memperoleh hasil belajar 7,0 ke atas dan 10 orang memperoleh hasil belajar di bawah 7,0. Dari hasil ini dapat diketahui bahwa prestasi belajar dalam dengan Metode Simulasi Kreatif dapat dikatakan belum berhasil secara optimal karena masih banyak siswa yang memperoleh hasil belajar di bawah 7,0 sebagai standar ketuntasan pembelajaran. Hasil ini akan diperbaiki dalam siklus II dan siswa yang telah berhasil akan dipertahankan, bahkan diusahakan untuk ditingkatkan pada siklus II.

Berdasarkan hasil yang telah diperoleh dan telah diklasifikasikan tentang tingkat hasil belajar siswa dalam dan gambar tunggal dengan Metode Simulasi Kreatif, maka diketahui bahwa rata-rata hasil belajar pertemuan pertama siklus II sebesar 7,36\%. Sementara distribusi hasil belajar PKn, dapat dilihat pada tabel di bawah ini:

Tabel 4.5. Distribusi Hasil Belajar Siswa Pertemuan Pertama Siklus II

\begin{tabular}{cccc}
\hline Perolehan Hasil Belajar & Kategori & Jumlah (n) & Persentase (\%) \\
\hline $0-4,0$ & Sangat Rendah & - & - \\
\hline $4,1-5,5$ & Rendah & - & - \\
\hline $5,6-7,0$ & Sedang & 13 & 59,09 \\
\hline $7,1-8,5$ & Tinggi & 8 & 36,36 \\
\hline $8,6-10$ & Sangat Tinggi & 1 & 4,55 \\
\hline Jumlah & & 22 & 100 \\
\hline
\end{tabular}

Pada tabel di atas menunjukkan bahwa tingkat hasil belajar siswa dengan perolehan hasil belajar, dari 22 siswa dengan Metode Simulasi Kreatif pada pertemuan pertama siklus II, tidak ada siswa yang memperoleh hasil belajar sangat rendah $(0-4,0)$ dan hasil belajar rendah $(4,1-5,5)$, hasil belajar sedang $(5,6-7,0)$ sebanyak 13 siswa atau 59,09\%, hasil belajar tinggi $(7,1-8,5)$ sebanyak 8 siswa atau $36,36 \%$, dan tidak ada hasil belajar sangat tinggi $(8,6$ 10) sebanyak 1 siswa atau $4,55 \%$.
Berdasarkan hasil yang telah diperoleh dan telah diklasifikasikan tentang tingkat hasil belajar siswa dalam membaca materi kedaulatan rakyat dan sistem pemerintahan di Indonesia dengan Metode Simulasi Kreatif, maka diketahui bahwa rata-rata hasil belajar pertemuan pertama siklus II sebesar 7,77\%.

Sementara distribusi hasil belajar PKn, pada pertemuan kedua siklus II dengan Metode Simulasi Kreatif dapat dilihat pada tabel di bawah ini:

Tabel 4.6. Distribusi Hasil belajar Siswa Pertemuan Kedua Siklus II

\begin{tabular}{cccc}
\hline Perolehan Hasil Belajar & Kategori & Jumlah (n) & Persentase (\%) \\
\hline $0-4,0$ & Sangat rendah & - & - \\
\hline $4,1-5,5$ & Rendah & - & - \\
\hline $5,6-7,0$ & Sedang & 7 & 31,82 \\
\hline
\end{tabular}


JIKAP PGSD: Jurnal Ilmiah Ilmu Kependidikan

\begin{tabular}{|c|c|c|c|}
\hline $7,1-8,5$ & Tinggi & 12 & 54,55 \\
\hline $8,6-10$ & Sangat Tinggi & 3 & 13,63 \\
\hline & & 22 & 100 \\
\hline
\end{tabular}

Pada tabel di atas menunjukkan bahwa tingkat hasil belajar siswa dengan Metode Simulasi Kreatif pada pertemuan kedua siklus II, tidak ada siswa yang memperoleh hasil belajar sangat rendah $(0-4,0)$ dan hasil belajar rendah $(4,1$ - 5,5), hasil belajar sedang $(5,6-7,0)$ sebanyak 7 siswa atau $31,82 \%$, hasil belajar tinggi $(7,1-8,5)$ sebanyak 12 siswa atau $54,55 \%$, dan hasil belajar sangat tinggi $(8,6-10)$ sebanyak 3 siswa atau $13,63 \%$.

Berdasarkan rekapitulasi data tabel di atas, maka dapat dideskripsikan sebagai berikut bahwa dari 22 siswa Kelas X.1 SMA Negeri 1 Bengo Kabupaten Bone bahwa pada pertemuan siklus II yang mengikuti pelajaran PKn dengan Metode Simulasi Kreatif, tingkat pencapaian rata-rata prestasi belajar pada siklus II sebesar 7,57, ini berarti telah mencapai hasil ketuntasan belajar secara klasikal yang diharapkan yakni sebesar $70 \%$.

Sementara distribusi rata-rata hasil belajar PKn, pada siklus II dengan Metode Simulasi Kreatif dapat dilihat pada tabel di bawah ini.

Tabel 4.7. Distribusi Rata-Rata Hasil Belajar Siswa Siklus II

\begin{tabular}{|c|c|c|c|c|c|c|}
\hline \multirow{2}{*}{$\begin{array}{l}\text { Perolehan Hasil } \\
\text { Belajar }\end{array}$} & \multirow{2}{*}{ Kategori } & \multicolumn{2}{|c|}{ Pertemuan Ke } & \multirow{2}{*}{ Jumlah } & \multirow{2}{*}{ Rata-Rata } & \multirow{2}{*}{$\begin{array}{c}\text { Persentase } \\
(\%)\end{array}$} \\
\hline & & 1 & 2 & & & \\
\hline $0-4,0$ & Sangat rendah & - & - & - & - & - \\
\hline $4,1-5,5$ & Rendah & - & - & - & - & - \\
\hline $5,6-7,0$ & Sedang & 13 & 7 & 20 & 10 & 45,45 \\
\hline $7,1-8,5$ & Tinggi & 8 & 12 & 20 & 10 & 45,45 \\
\hline \multirow[t]{2}{*}{$8,6-10$} & Sangat Tinggi & 1 & 3 & 4 & 2 & 9,10 \\
\hline & & 22 & 22 & 44 & 22 & 100 \\
\hline
\end{tabular}

Pada tabel di atas menunjukkan bahwa rata-rata tingkat hasil belajar siswa dengan perolehan Hasil belajar, dari 22 siswa dengan Metode Simulasi Kreatif pada siklus I, tidak ada siswa yang memperoleh hasil belajar sangat rendah $(0-4,0)$ dan hasil belajar rendah $(4,1$ $5,5)$, hasil belajar sedang $(5,6-7,0)$ sebanyak 10 siswa atau $45,45 \%$, hasil belajar tinggi $(7,1-8,5)$ sebanyak 10 siswa atau $45,45 \%$, dan yang tidak memperoleh hasil belajar sangat tinggi $(8,6-10)$ sebanyak 2 siswa atau 9,10\%.

Jumlah siswa yang tuntas dalam pembelajaran PKn di akhir siklus II telah mencapai 22 orang atau $100 \%$. Dari hasil belajar dapat ditentukan tingkat prestasi belajar membaca materi kedaulatan rakyat dan sistem pemerintahan di Indonesia. Secara rinci dapat digambarkan seperti pada tabel berikut ini.

Tabel 4.8. Klasifikasi Tingkat Prestasi Belajar Siswa Siklus II

\begin{tabular}{cccc}
\hline No & Perolehan Hasil Belajar & Frekuensi & Persentase \\
\hline 1 & Hasil belajar 7,0 ke atas & 22 & 100 \\
\hline 2 & Hasil belajar di bawah 7,0 & - & - \\
\hline & Jumlah & 22 & 100 \\
\hline
\end{tabular}

Berdasarkan hasil yang telah diperoleh dan telah diklasifikasikan tentang tingkat prestasi belajar dengan Metode Simulasi Kreatif, maka diperoleh data bahwa pada siklus II yaitu 22 siswa atau $100 \%$ yang memperoleh hasil belajar di atas 7,0 dan 0 siswa atau $0 \%$ yang memperoleh hasil belajar di bawah 7,0. Dari hasil ini dapat diketahui bahwa prestasi beiajar dalam membaca materi kedaulatan rakyat dan sistem pemerintahan di Indonesia dengan
Metode Simulasi Kreatif dapat dikatakan telah berhasil secara optimal.

\section{SIMPULAN DAN SARAN}

Sesuai dengan hasil penelitian, maka dapat disimpulkan bahwa Metode Simulasi Kreatif dapat meningkatkan kreativitas dan hasil belajar siswa. Hal ini dapat dilihat pada hasil penelitian yang menyatakan bahwa kreativitas siswa mengalami peningkatan pada saat guru 
menggunakan metode role playing dan simulation pada pelajaran Kedaulatan Rakyat dan Sistem Pemerintahan di Indonesia. Peningkatan ini dapat dilihat baik pada setiap siklus pada kelas terteliti. Jika dibandingkan hasil belajar Kedaulatan Rakyat dan Sistem Pemerintahan di Indonesia pada siklus I dengan siklus II, maka terjadi peningkatan dari 6,93 pada siklus I meningkat menjadi 7,57 pada siklus II. Untuk komponen aktivitas guru dalam membelajarkan mated kedaulatan rakyat dan sistem pemerintahan di Indonesia, meningkat dari $65,5 \%$ pada siklus I meningkat menjadi $92,3 \%$, pada siklus II.

Berdasarkan hasil penelitian ini, diajukan saran:

1. Guru hendaknya menerapkan metode yang bervariasi dalam pembelajaran $\mathrm{PKn}$, antara lain dengan menggunakan metode role playing dan simulation untuk membantu kreativitas siswa memahami materi PKn.

2. Guru hendaknya menggali potensi yang dimiliki siswa dengan menerapkan metode pembelajaran yang menciptakan suasana yang baik untuk siswa dan dapat mengarahkan siswa mengembangkan potensi yang dimiliki.

3. Mengingat bahwa Metode Simulasi Kreatif dapat meningkatkan potensi siswa, terutama kreativitas siswa, maka diharapkan guru dapat menerapkan Metode Simulasi Kreatif dalam pembelajaran PKn.

\section{DAFTAR RUJUKAN}

Ahmadi, Abu dan Joko Tri Prasetya. 2005. Strategi Belajar Mengajar. Bandung: Pustaka Setia.

Aminuddin. 2008a. Simulasi Kreatif Anak. Jakarta: Balai Pustaka

Mata Pelajaran". Vokal. No.l Thn. V Desember 1994 (Hal. 1-3).

Bahri, D.S. 2004. Prestasi Belajar dan Kompetensi Guru. Surabaya: Usaha Nasional. Dahlan, Saronji. 2008. Pendidikan Kewarganegaraan. Jakarta: Erlangga.

Depdiknas. 2003. Undang-Undang Republik Indonesia tentang Sistem Pendidikan Nasional. Jakarta: Dirjen Pendidikan Dasar dan Menengah.

Depdikbud. 2004. KamusBesarPKnEdisiW. Jakarta: Balai Pustaka.
Direktorat Jendral Pendidikan Tinggi. 2007. Kapita Selekta Pembelajaran. Jakarta: Depdiknas.

Hidayat, Kosasi, dkk. 2007. Strategi BelajarMengajar PKn Bandung: Bina Cipta.

Kartawidjaya, Eddy Soewandi. 2007. Kamus Ensiklopedia Pendidikan. Jakarta: PT Rineka Cipta.

Kartono, Kartini. 2009. Teori Kepribadian Bandung: Penerbit Alumni.

Purwanto, Ngalim M.. 2005. Ilmu Pendidikan Teoretis dan Praktis. Bandung: PT Remaja Rosdakarya.

Rahman, Abdul. 2003. "Faktor yang Mempengaruhi Kurangnya Minat Siswa Kelas IX SMA Hang Tuah Negeri 4 Pancajirang terhadap Pelajaran PKn". Skripsi. Ujung Pandang: IKIP Ujung Pandang.

Rofi'uddin, A. 2002. Metode Penelitian Kualitatif dalam Pengajaran PKn. Bahan Ajar Mata Kuliah Penelitian Pengajaran $P K n$ Malang: PPS UM

Sahabuddin, H. 2004. Mengajar dan Belajar (Dua Apek dari Suatu Proses yang Disebut Pendidikan). Makassar: FIP UNM.

Sardinian. A.M. 2002. Interaksi dan Motivasi Belajar Mengajar. Jakarta: Rajawali Press.

Silitonga, Mangasa. 2008. Pengantar Tata bahasa Transformasi. Jakarta: Depdikbud.

Slameto. 2003. Belajar dan Faktor-faktor yang Mempengaruhi. Jakarta: PT Rineka Cipta.

Tarigan, H.G. 2000a. Membaca sebagai Suatu Keterampilan Berbahasa. Bandung: Angkasa.

-------. 2000b. Telaah Buku Teks PKn. Bandung: Angkasa.

The Liang Gie. 2004. Cara Belajar Efisien Yogyakarta: Penerbit Liberty Yogya.

Ummah, Khairul, dkk. 2003. SEPIA Kecerdasan Milyuner. Jakarta: Aha.

Umar, Alimin \& Nurbaya Kaco. 2008. Penelitian Tindakan Kelas (Pengantar ke dalam Konsep dan Aplikasi). Makassar: Badan Penerbit UNM.

Wiriaatmadja, Rochiati. 2005. Metode Penelitian Tindakan Kelas. Bandung: Remaja Rosdakarya.

Wood dan Attfield, 1996. Language Arts. A Process Approach. Madison, Wisconsin: Brown \& Benchmark. 